\title{
Optimizing the Formulation of Soyabean- Peanut Beverage of Chocolate-Flavored with Acceptable Rheological Properties
}

\author{
S Elizabeth Amudhini Stephen, Seihenbal.G.S.S
}

\begin{abstract}
This paper aims to evaluate the rheological properties for the preparation of chocolate flavored soybean-peanut beverage from the different combination of soybean, peanut and cocoa powder. A Box-Behnken design with three independent variables (soybean, peanuts and chocolate) and the dependent variables (acidity, brix and viscosity) produced 12 formulations. The optimized formulation determined from the data contained soy beans $40.76 \mathrm{~g} / 100 \mathrm{~g}$, peanuts $38.28 \mathrm{~g} / 100 \mathrm{~g}$ and chocolate 5.66 $\mathrm{g} / \mathbf{1 0 0 g}$. It was also observed that soy protein provides better result than soy flour and influence beverage characteristics.

Keywords: Response surface methodology, optimization,
\end{abstract} beverage, acidity, brix, viscosity, responses, peanuts, soybeans

\section{INTRODUCTION}

Peanut also known as groundnut is an important legume and food crop produced in native to South America. In western countries the kernel of peanut is used for oil production and as a raw material in cooking dishes. It is enriching in proteins, fibre and polyphenols. It is stated by Akinyele and Adudu that peanuts have high carbohydrate content than cowpeas.

The soybean (Glycine max) is the seed from a leguminous soybean plant. It has high protein content and an ideal source of protein supplementation of starchy foods. (Maha et al. 2011). The protein present in soy lowers cholesterol levels. Soybeans also contain biologically active or metabolic proteins such as enzymes, trypsin inhibitors, hemagglutinins, and cysteine protease. The proteins from the stored soy cotyledon are important for human nutrition. The isoflavones are said to have potential anticancer effects. (Venkateswari et al 2016). It can use as a replacement for wheat in noodles which is also a rich source lysine. Economically high priced meat protein is present in soybean and observed to be the good source of protein especially in vegetarian diet. The nutrient level of pregnant woman, nursing mother, school going and young children can be increased by high protein soya. (Pakhareet al. 2016). Soy milk is a rich slimy liquid with aflavor of nut prepared by soaking soybean with water to produce a nutritional drink which is found to be more

Revised Manuscript Received on April 11, 2020.

* Correspondence Author

S,Elizabeth Amudhini Stephen*, Associate Professor, Department of Mathematics, Karunya Institute of Technology and Sciences, Coimbatore, India. elizi.felix@gmail.com

Seihenbal,G,S, Department of Food Processing, Karunya Institute of Technology and Sciences, Coimbatore

(C) The Authors. Published by Blue Eyes Intelligence Engineering and Sciences Publication (BEIESP). This is an open access article under the CC BY-NC-ND license (http://creativecommons.org/licenses/by-nc-nd/4.0/) nutritionally than normal milk. The main objective of the study was to optimize the use of soybeans, peanuts and cocoa powder for theproduction of a chocolate-flavored, soy-peanut beverage with acceptable chemical, and physicochemicalproperties employing a three-component constrained.

\section{Analytical methods:}

\section{Rheological properties}

The study determines the rheological properties of the chocolate flavored soy-peanuts beverage which included acidity, viscosity and brix.

\section{Acidity:}

AOAC method was used to determine the acidity of the product.

\section{Apparent viscosity:}

A Brookfield digital viscometer was used for this study

Brix:

Brix is used as a quality control parameter and is measured by refractometer.

\section{MATERIALS AND METHODOLGY:}

\section{Materials}

Soybeans, peanuts, soy lecithin, gum based stabilizer, cocoa powder and sugar were used.

\section{Experimental design:}

Here in this study soy bean, peanut and chocolate is used as a dependent variables $(\mathrm{Y})$, acidity $\left(\mathrm{Y}_{1}\right)$, viscosity $\left(\mathrm{Y}_{2}\right)$, brix level $\left(\mathrm{Y}_{3}\right)$. The independent variables are soybean (A), peanuts (B), chocolate(C). 12 runs were made to optimize the response. Table 1 , determines the response and variables used in the experiments,

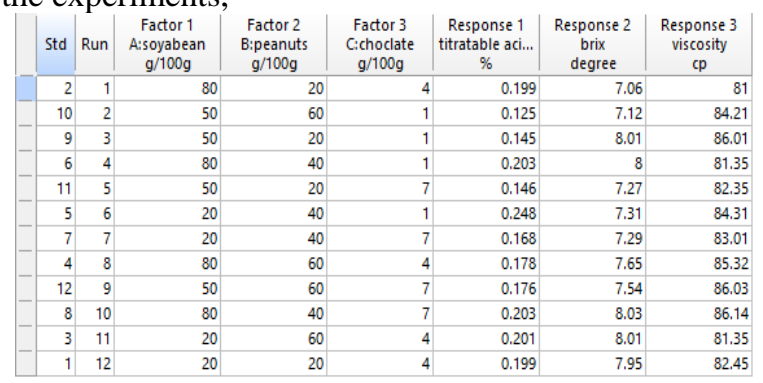

Fig1: experimental design.

\section{Published By:}

Blue Eyes Intelligence Engineering \& Sciences Publication

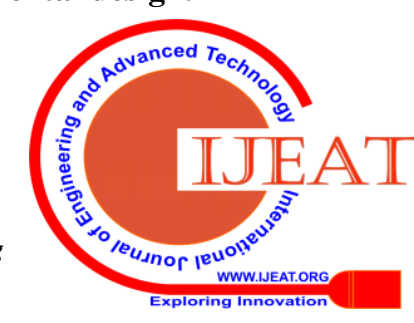




\section{RESULT AND DISCUSSION:}

\section{Effect of independent variables on acidity}

The acidity is the measure of sourness (acid present) of beverage. It was measured as percent lactic acid. From the figure1, it was observed that percent acidity increases with increase in soybean and peanut concentration.

Titratableacidity $=0.254986-0.000643 \mathrm{X}_{1}-0.000410 \mathrm{X}_{2}-0.020611 \mathrm{X}_{3}-9.58333 \mathrm{X}$ ${ }_{1} \mathrm{X}_{2}+0.000222 \mathrm{X}_{1} \mathrm{X}_{3}+0.000208 \mathrm{X}_{2} \mathrm{X}_{3}$
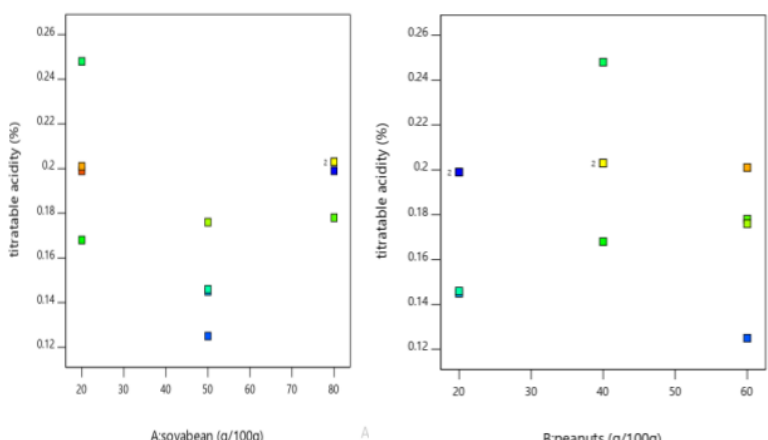

(a) (b)
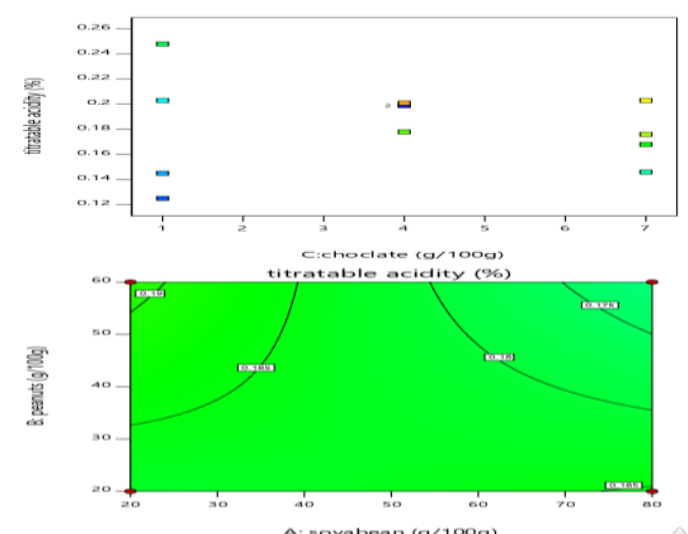

Fig2.variables on titratable acidity

\section{Effect of independent variables on brix}

Brix is the sugar content of any aqueous solution $\left(1^{\circ} \mathrm{C}=1 \mathrm{~g}\right.$ of sucrose in $100 \mathrm{~g}$ of solution). It also states about the total solid dissolved in a given medium of soy-peanut beverage. The regression model obtained for brix is;

Brix $\left(\mathrm{Y}_{2}\right)=+8.85278-0.008639 \mathrm{X}_{1}-0.030188 \mathrm{X}_{2}-0.213194$ $\mathrm{X}_{3}+0.000221 \mathrm{X}_{1} \mathrm{X}_{2}+0.000139 \mathrm{X}_{1} \mathrm{X}_{3}+0.004833 \mathrm{X}_{2} \mathrm{X}_{3}$
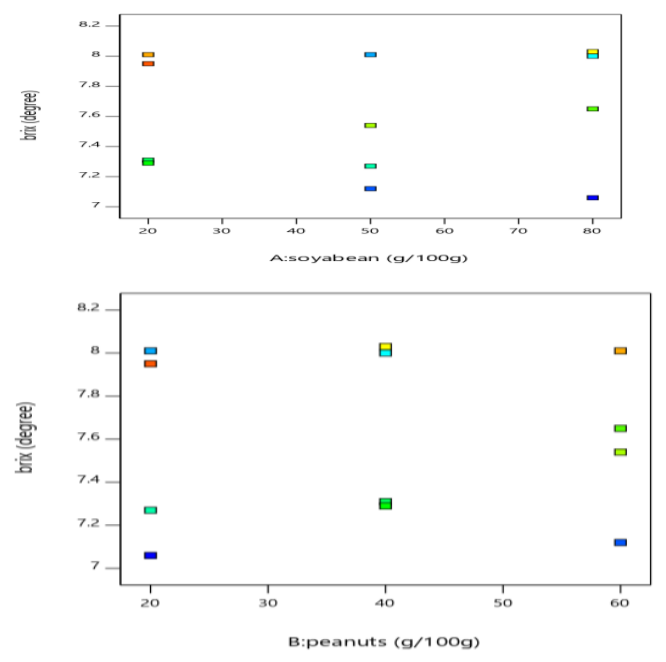
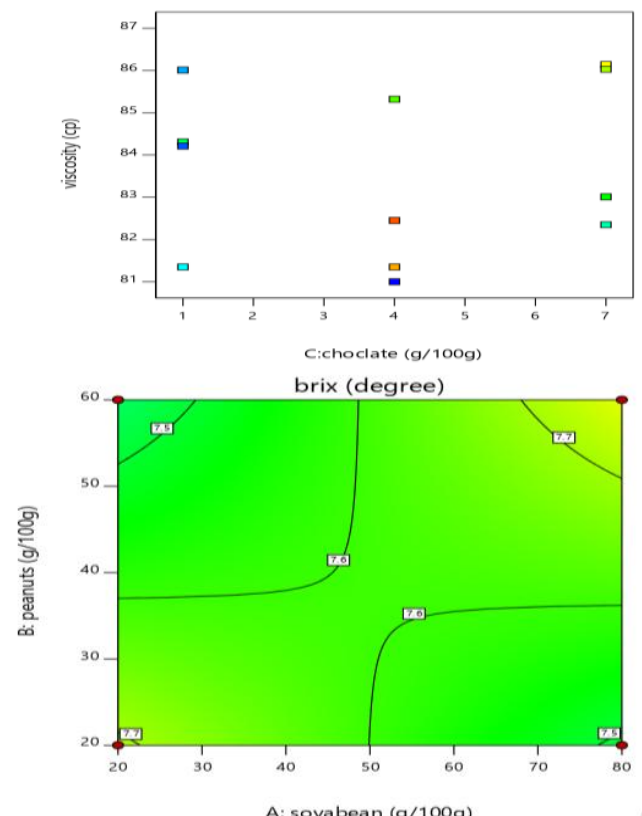

Fig3 .Effect of independent variables on viscosity Effect of independent variables on viscosity:

Viscosity of the product can be determined by Ostwald viscometer. The viscosity of the beverage varies for each trails. Viscosity increases with increase in peanut concentration and decreases with soybean concentration. The regression model obtained for the viscosity of the product: Viscosity $\left(\mathrm{Y}_{3}\right)$ $=93.07042-0.146792 \mathrm{X}_{1}-0.172375 \mathrm{X}_{2}-1.69042 \mathrm{X}_{3}+0.002258$ $\mathrm{X}_{1} \mathrm{X}_{2}+0016917 \mathrm{X}_{1} \mathrm{X}_{3}+0.022833 \mathrm{X}_{2} \mathrm{X}_{3}$
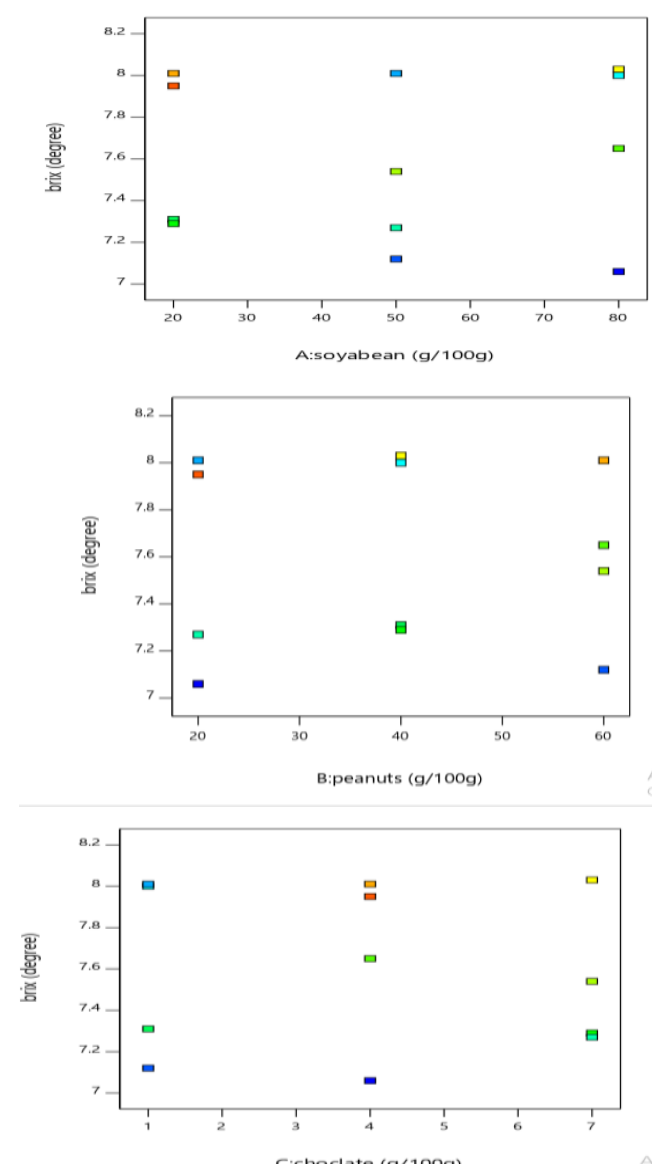

Published By:

Blue Eyes Intelligence Engineering \& Sciences Publication

(C) CoDvriaht: All riahts reserved. 


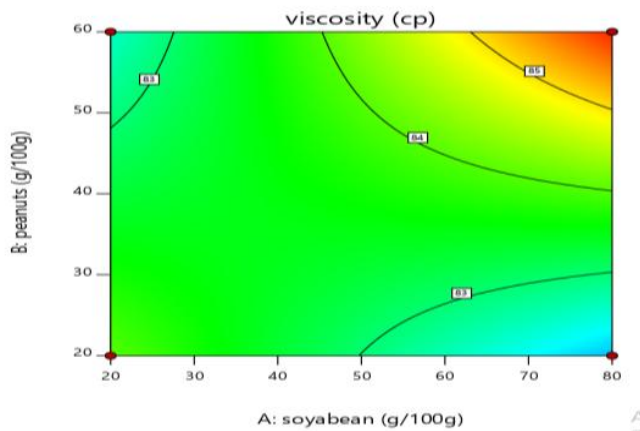

Fig4

\section{CONCLUSION:}

The study defines the optimization of the product with standard level of rheological properties using box behnken design. The optimised end product contain acidity ranging between $0.178 \%-0.299 \%$, brix $7.56^{\circ}-8.90^{\circ}$ and viscosity 83.29-87.80 cp. By using the optimized procedure, the product can be produced in industrial level. Overall acceptability and sensory score of soy-peanut chocolate-flavoured milk beverage in the Indian market are the further research work.

\section{REFERENCES:}

1. Aidoo, H., Sakyi-Dawson, E., Tano-Debrah, K. and Saalia, F. K. (2010). Development and characterization of dehydrated peanut-cowpea milk powder for use as a dairy milk substitute in chocolate manufacture. FoodResearch International, 43:79-85

2. Akinyele, I. O. and Abudu, I. A. (1990). Acceptability and nutrient content of milk substitutes from four cultivars of cowpeas (Vignaunguiculata). Journal of Food Science, 55: 701-707.

3. AOAC (1990). Official Methods of Analysis Association of Official Analytical Chemists, 15

4. Carrão-Panizzi, M. C., Beléia, A. P., Prudêncio-Ferreira, S. H., Oliveira, M. C. N. and Kitamura, K. (1999). Effects of Isoflavones on Beany Flavor and Astringency of Soymilk and Cooked Whole Soybean Grains. Pesquisa a gropecuária Brasileira, Brasília, 34, (6):1044-1052.

5. Deshpande, R. P., Chinnan, M. S. and Phillips, R. D. (2008). Process development of a chocolate flavored peanut-soy beverage. International Journal of Food Science and Technology, 43 (5): 886-896 (9)

6. Hajirostamloo, B. (2009). Comparison of nutritional and chemical parameters of soymilk and cow milk, World Academy of Science, Engineering and Technology, pg .57

7. Maha A. M. Ali, A. H. (2012). Effect of Different Supplementation Levels of Soybean Flour on Pearl Millet Functional Properties. Food and Nutrition Sciences, , 1-6.

8. Mulando, T. M. M. and Resurreccion, A. V. A. (2006). Peanut Extract and Emulsifier Concentration affect Sensory and Physical Properties of Liquid Whitener. Journal of Food Science, 59(2): 344-349.

9. Pakhare KN, D. A. (2016). Studies on Preparation and Quality of Nutritious Noodles by Incorporation of defatted rice bran and soy flour. Journal of Food processing and technology , 7-11.

10. Parameshwari, P. V. (2016). Effect of incorporation of soya flour to wheat flour on nutritional and sensory quality of biscuits. International Journal of Applied Research , 827-832.

11. Tamime, A. Y. and Robinson, R. K., (1999). Yogurt Science and Technology. Cambridge, UK: Woodhead Publishing Ltd.. Washington D.C., Pp 992-995.

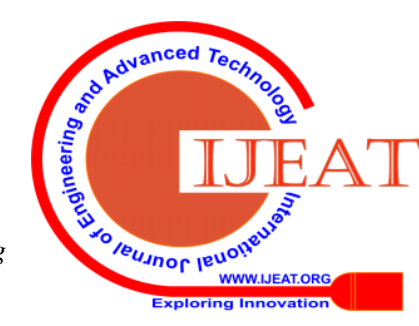

